\title{
Coopetition in Temporary Contexts: Examining Swift Trust and Swift Distrust in Humanitarian Operations
}

\author{
Sarah Schiffling and Claire Hannibal \\ Liverpool Business School, Liverpool John Moores University, Liverpool, UK \\ Yiyi Fan \\ Department of Management Science, Lancaster University, Lancaster, UK \\ Matthew Tickle \\ Management School, University of Liverpool, Liverpool, UK
}

\begin{abstract}
Purpose - By drawing on commitment-trust theory, we examine the role of swift trust and distrust in supporting coopetition under conditions of uncertainty and interdependence in the setting of humanitarian disaster relief organisations.
\end{abstract}

Design/methodology/approach - This paper presents findings from case studies of 18 international humanitarian relief organisations based on 48 interviews and the analysis of publicly available documents.

Findings - We find that both swift trust and swift distrust support coopetition. As coopetition is simultaneous cooperation and competition, in this study we show how swift trust and swift distrust also occur simultaneously in coopetitive contexts.

Research limitations/implications - Coopetition as a strategic choice is well-researched in the private sector, yet has received less attention in the nonprofit sector, particularly in contexts that are shaped by interdependence and uncertainty. We show the importance of swift trust and swift distrust in coopetitive relationships by drawing on commitment-trust theory.

Practical implications - In focusing on a competitive environment in which cooperation is essential, we find limited choice of coopetitive partners. Humanitarian relief organisations must often simply work with whichever other organisations are available. We highlight how trust and distrust are not opposite ends of a spectrum and detail how both contribute to coopetitive relationships.

Originality/value - Our findings contribute to commitment-trust theory by explaining the important role of distrust in forging coopetitive relationships. Furthermore, we contribute to prior work on coopetition by focusing on an uncertain and interdependent nonprofit environment. 
Keywords: Temporary operations, Coopetition, Swift trust, Swift distrust, Humanitarian logistics

Article Type: Research Paper 


\section{Introduction}

There is considerable support for the role of interorganisational trust in improving the performance of alliances (Mohr and Speckman, 1994, Zaheer et al., 1998, Johnston et al., 2004), particularly under conditions of uncertainty and interdependence (McEvily et al., 2003, Krishnan et al., 2006). Studies show how interorganisational trust reduces the potential for conflict (Zaheer et al., 1998), mitigates fear of opportunistic behaviour (Saxton, 1997) and increases knowledge sharing (Nielsen and Nielsen, 2009). Research conceptualises trust as a choice (Kramer, 1999, Li, 2017) and calls for further studies examining trust under conditions where knowledge is lacking and there are negative consequences for the trustor (Li, 2017). Such conditions are pertinent to those of coopetition (Kostis and Näsholm, in press).

Conceptualised as simultaneous cooperation and competition between organisations (Brandenburger and Nalebuff, 1996), coopetition is considered as a strategic choice (Ritala, 2012). For nearly three decades organisational strategists have acknowledged that competitive advantage can be achieved by collaborating with industrial rivals (Bleeke and Ernst, 1993). In many instances, particularly in the private sector, coopetition is used as a mechanism to reduce costs (Czernek and Czakon, 2016), increase knowledge flows (Tsai, 2002), increase access to key resources (Gupta and Govindarajan, 1999), increase technology adoption (Lado et al., 1997), accelerate innovative output (Liu, 2013), or increase supply chain resilience (Bakshi and Kleindorfer, 2009). Coopetition in the nonprofit context has received markedly less research and managerial attention than that of the private sector. We find this to be surprising given the competitive environment within which nonprofit organisations must often collaborate to deliver outcomes (Austin and Seitanidi, 2012). Nonprofit organisations are competing for funds and exposure, whilst simultaneously forming sectoral consortia and partnerships to deliver services (Best et al., 2018). Further, often implicit in literature examining coopetition is the assumption that organisations have a choice of competitive partners with which to collaborate (Gnyawali et al., 2016, Le Roy and Czakon, 2016). In the nonprofit context this is not necessarily the case, particularly for temporary operations where deliverables are time pressured (e.g. nonprofit services providing support for rough sleepers during unexpected severe weather conditions). In such situations, collaboration with competitors must occur quickly.

In the nonprofit sector there are increasing demands on organisations to engage in coopetition, yet there is limited research examining how this can or should be done. In addition to the 
sectoral context, there is also limited research examining coopetition in temporary situations, particularly those in which speed of response is crucial. We are therefore interested in combining both of these themes to examine coopetition in the time pressured temporary setting of humanitarian disaster relief operations. In their seminal paper Morgan and Hunt (1994) argue in support of commitment and trust, rather than power, as crucial in building and maintaining relationships with exchange partners. This line of argumentation echoes research by Parkhe (1993) that finds trust and commitment as integral to interorganisational relationships. The notion of the importance of trust and commitment over power is salient for humanitarian relief operations that must assemble and work together quickly and effectively, sometimes for the first time, to ensure outcomes are delivered.

We therefore draw on commitment-trust theory to frame our study and are guided by the premise that interorganisational relationships that are characterised by commitment and trust generate the collaborative practice of cooperation (Morgan and Hunt, 1994, Dubey et al., 2019a). We also acknowledge research suggesting that too much trust may have detrimental effects on performance (Patzelt and Shepherd, 2008, Skinner et al., 2014). We draw on the concepts of swift trust and swift distrust (Meyerson et al., 1996, Adler, 2005, Adler, 2007) to examine facets of coopetition under conditions of uncertainty and interdependence. Developed by Meyerson et al. (1996), swift trust is concerned with developing trust in temporary settings and is a collective form of managing issues of vulnerability, uncertainty, risk and expectations. Differing from trust built over time, swift trust concerns temporary teams with a clear purpose, common task and finite lifespan (Adler, 2007, Blomqvist and Cook, 2018). Because swift trust relies on category driven information, Meyerson et al. (1996) also refer to the concept of swift distrust, based on suspicion and mistrust arising from this category driven information, which can occur as rapidly as swift trust. Studies on humanitarian operations have examined the concept of swift trust (Tatham and Kovács, 2010, Lu et al., 2018, Dubey et al., 2019a, Dubey et al., 2019b), yet to date there has been limited research that considers swift distrust.

Our paper is structured as follows; we firstly examine literature on commitment and trust in coopetitive humanitarian relief operations with a particular focus on swift trust and distrust. We next detail our qualitative research design that drew on case studies of humanitarian organisations (HOs) based on interviews with international humanitarian relief professionals and the analysis of publicly available documents pertaining to coopetition in this environment. We then present the findings of our study showing that both swift trust and swift distrust 
support coopetition. Subsequently, we detail the implications our work has on research and practice, as well as our contribution to theory while acknowledging the limitations of the study and offering suggestions for future studies.

\section{Conceptual framing}

\subsection{Commitment and trust in coopetitive humanitarian relief operations}

The coordination of humanitarian relief organisations is essential to the success of humanitarian operations (Balcik et al., 2010, Moshtari, 2016). Scholars argue that coordination is predicated on a shared commitment to cooperate, particularly from those actors directly involved in the field (Kabra and Ramesh, 2015). Further, commitment is influenced by trust (Morgan and Hunt, 1994, De Ruyter et al., 2001). As per Dubey et al. (2019a), we therefore draw on commitment-trust theory (Morgan and Hunt, 1994) to frame our study of humanitarian relief operations and focus on the coopetition context. Coopetition is conceptualised as simultaneous cooperation and competition between organisations (Brandenburger and Nalebuff, 1996). It is important to note from the outset that it is the simultaneity of cooperation and competition that underpins the construct; coopetitive relationships are not either collaborative or competitive, they are engaging in both at the same time (Bengtsson and Kock, 2014). A coopetitive strategy has potential to enable the actors providing humanitarian relief, which are primarily non-governmental organisations (NGOs) in conjunction with governments, local communities, businesses and the military (Kovács and Spens, 2008), to simultaneously cooperate to provide relief to those affected by disaster (Schulz and Blecken, 2010) whilst at the same time competing for financial resources and for media attention (Balcik et al., 2010). In terms of trust, coopetition therefore engenders interdependence, uncertainty and concerns about opportunism (Kostis and Näsholm, in press).

Originally studied from a dyadic perspective, coopetition is advantageous in that it has potential to improve performance by, on the one hand, fostering collaboration and its associated benefits, and on the other forcing organisations to enter competitive relationships and thus focus on performance gains (Bengtsson and Kock, 2000). Hence, organisations that adopt a coopetitive strategy can benefit from the advantages of both collaborative and competitive relationships (Le Roy and Czakon, 2016). The scope of coopetition has been refined since its inception and has developed from a dyadic perspective to include multiple actors in horizontal and vertical coopetitive relationships (Bengtsson and Kock, 2014). Ritala (2012) outlines three motives for organisations engaging in coopetition; increasing the size of the market or creating a new one, 
efficiency in resource utilisation, and improvement in the firm's competitive position. Studies highlight the strategic benefits of coopetition as cost savings (Czernek and Czakon, 2016), increased knowledge flows (Tsai, 2002), increased access to key resources (Gupta and Govindarajan, 1999), increased technology adoption (Lado et al., 1997), accelerating innovative output (Liu, 2013), and increased supply chain resilience (Bakshi and Kleindorfer, 2009).

Humanitarian relief operations have been described as a hastily formed network (Denning, 2006, Tatham and Kovács, 2010) and in utilising a coopetitive approach value is created collectively through the efforts of the humanitarian sector whilst simultaneously appropriated by individual actors in the form of, for example, increased donations and higher levels of visibility. This simultaneous creation of common value and realisation of private benefits when parties with different identities, motives and goals engage in a particular project has been labelled as the coopetition paradox (Gnyawali et al., 2016). It is recognised that no single HO has the capacity and capability to meet the needs of large-scale humanitarian disaster, and hence collaborative practices are essential (McLachlin and Larson, 2011, Dubey et al., 2019a). It is also recognised that competition between HOs is fierce (Oloruntoba and Gray, 2006, Herlin and Pazirandeh, 2012), with each organisation having to emphasise its own contribution to elicit funding and donations (Fawcett and Fawcett, 2013). Competition for media coverage in particular becomes increasingly intense, with media attention likely to increase the amount of donations received (Van Wassenhove, 2006, Wakolbinger et al., 2013). A strategy of coopetition has the potential to enable humanitarian relief outcomes to be achieved by a collective of humanitarian actors whilst simultaneously increasing funding and access to resources for individual organisations.

HOs work collectively on a particular relief operation for a particular period of time (Jahre et al., 2009). Because of the temporary context, in one sense the coopetitive relationships between actors delivering humanitarian relief are also temporary as once the project is completed this collection of actors will disband. Yet in another sense these relationships are enduring as there is the very real possibility that the same actors, particularly international NGOs, are in longerterm relationships with some or all of these actors, and/or will be involved in subsequent collective humanitarian relief operations with the same organisations. It is therefore possible that knowledge and experience gained from pre-existing relationships will be utilised in tackling subsequent disaster relief projects. The quasi-temporary nature of the coopetitive 
relationships between humanitarian actors therefore provides a novel backdrop to examining the coopetition paradox as it adds a temporal dimension.

\subsection{Swift trust, distrust, and humanitarian relief operations}

Scholars suggest that to overcome the tensions of the coopetition paradox, organisations need to develop a new shared perspective (Gnyawali et al., 2016). Therefore in the context of coopetition, and in recognising the often temporary, ad hoc and informal nature of humanitarian relief operations, we examine the notion of swift trust as a mechanism for developing this new shared perspective (Meyerson et al., 1996, Tatham and Kovács, 2010). Trust is often considered to develop over time (Mayer et al., 1995, Kramer, 1999). Hastily formed networks may not necessarily have time to develop and maintain trust through the traditional activities of familiarity, shared experience and fulfilled promises (Meyerson et al., 1996). Instead, hastily formed networks, such as humanitarian relief operations, must formulate trusting relationships quickly; a concept termed as swift trust (Meyerson et al., 1996). For swift trust to develop, the behavioural expectations of the group of actors is defined in terms of tasks and specialties rather than personalities (Meyerson et al., 1996)

Researchers have utilised the notion of swift trust when examining humanitarian relief operations (for a summary of these works see e.g. Lu et al., 2018). Studies show how the rapid formulation of trusting relationships increases the speed at which actors start sharing information and hence reduces uncertainty (Lu et al., 2018, Dubey et al., 2019a), enhances humanitarian supply chain visibility and improves the level of coordination (Dubey et al., 2018). Swift trust has also been considered in the context of unexpected and dangerous situations, for example terrorist attacks, avalanches, explosive fires or mass casualties in road traffic accidents, as those first on the scene in these instances are often strangers who have never worked together before (Olsen, 2018). As per these examples, building swift trust must happen immediately and hence it forms rapidly in response to a different set of antecedents than that of history-based conventional trust that takes time to build (Altay and Pal, 2014, Olsen, 2018). In line with Kramer's (1999) bases of trust within organisations, and building on Hung et al.'s (2004) examination of swift trust, Tatham and Kovács (2010) consider the antecedents to swift trust in the humanitarian context as third-party information, dispositional trust (general disposition to trusting others), rules, categories, and roles. 
Further, in considering swift trust, Hung et al. (2004) propose three routes to developing a trusting relationship; peripheral, central and habitual. Based on phases over time, Hung et al. (2004) argue that when people first meet, and have no prior knowledge, they adopt the peripheral route to trust that is predicated on using peripheral cues such as categories, roles, organisational norms and third-party information. This route to trust relies on category-driven information processing (Hung et al., 2004). As individuals develop knowledge of each other, the central route to trust is employed. This is based on the active evaluation of trustworthiness using the antecedents of perceived ability, integrity and benevolence (Hung et al., 2004). Over a longer time period, individuals may utilise the third route to trust, habitual, which is built upon the accumulated knowledge of the relevant parties (Hung et al., 2004). Drawing on Hung et al.'s (2004) framework, Tatham and Kovács (2010) consider the peripheral route to swift trust to be the most appropriate for humanitarian operations. This is due to limited interaction history and time constraints, which leads humanitarian actors to rely on peripheral cues (Hung et al., 2004, Tatham and Kovács, 2010). These findings are supported by a recent empirical study of humanitarian workers in Southeast Asia (Lu et al., 2018).

In recognising the role of trust, studies also highlight the concept of distrust. Suspicion is inherent in interorganisational relationships (Kramer, 1999) and is considered one of the central tenets of distrust (Deutsch, 1958). Antecedents of distrust include forewarnings of insincerity or untrustworthiness (Fein, 1996) and category-based distrust (Brewer, 1981). Scholars posit that trust and distrust are both concerned with certainty; trust is concerned with expectations of what is hoped for and distrust about what is feared, and hence trust and distrust are not opposite ends of a continuum and exist simultaneously (Lewicki et al., 1998). Swift distrust has received less research attention than distrust. Referred to briefly by Meyerson et al. (1996) as contrary to swift trust, studies to date have mainly focused on simulations examining the impact of swift distrust on scenario outcomes (Adler, 2005, Adler, 2007). Following the conceptualisation of the simultaneous nature of trust and distrust, we draw on swift trust and swift distrust as offering helpful insights for our study of humanitarian operations.

\subsection{Summary and development of research question}

Much of the extant research examining the phenomenon of coopetition has done so from a private sector perspective (Ritala, 2012, Gnyawali et al., 2016, Le Roy and Czakon, 2016). There has been limited consideration of the phenomenon in nonprofit contexts. This is surprising given the competitive environment within which nonprofit organisations must often 
collaborate to deliver outcomes (Austin and Seitanidi, 2012). Nonprofit organisations are competing for funds and exposure on the one hand, and forming sectoral consortia and partnerships to deliver services on the other (Best et al., 2018). Further, within coopetition literature there is often the implicit assumption that organisations have choice over which of their competitors they wish to collaborate with (Gnyawali et al., 2016, Le Roy and Czakon, 2016). In a nonprofit context this is not always the case. We therefore wish to extend current research on coopetition by examining its application to a complex, temporary, multistakeholder context and therefore situate our study in humanitarian relief operations. In this context trust must be developed quickly between coopetitive partners as speed of response is essential (Van Wassenhove, 2006, Kovács and Spens, 2007). There may also be a limited pool of potential partners that share similar organisational structures, policies, missions and political positions, resulting in HOs having to collaborate with whichever organisations are available to deliver relief outcomes (Dolinskaya et al., 2011).

Commitment and trust are integral to interorganisational relationships and have been shown to improve performance, particularly in uncertain situations shaped by interdependence. By drawing on commitment-trust theory, we examine the role of swift trust and swift distrust in supporting coopetition between humanitarian disaster relief organisations and thus ultimately shaping the ability of the humanitarian system to respond to disasters. We frame our study by posing the following research question:

How do swift trust and swift distrust support coopetition under conditions of uncertainty and interdependence?

\section{Research methodology}

\subsection{Research design and setting}

Humanitarian relief is often considered as temporary as it adopts a time limited organisational form around a shared purpose (Cavdur et al., 2016, Fernandes et al., 2018). We use a multiple case research design to enable in-depth investigation of the phenomenon of interest, which is suitable for answering a "how" research question like ours (Easton, 2010, Voss et al., 2016). To develop deep insights to help us address the research question, we drew on data gathered from qualitative interviews and publicly available documents. As it was anticipated that the research would lead to an elaboration of commitment-trust theory, we adopted a theory elaboration case study design to extend prior work and stimulate future studies (Ketokivi and Choi, 2014, Bansal et al., 2018). While individuals form trusting relationships at the micro 
level, these then have organisational responses at the meso level, which generate macro scale consequences (Tidström and Rajala, 2016). Thus, the case study approach with input from individuals, as well as a review of organisational documents, offers an appropriate methodological fit with the research question (Tidström and Rajala, 2016).

In a humanitarian relief setting, coopetition is concerned with relationships between HOs: a wide array of different actors coming together in hastily formed networks to deliver assistance to those affected by disaster, while simultaneously competing for financial resources (i.e. donations) and media attention (Tatham and Kovács, 2010). Thus, our case studies as "rich empirical instance of some phenomenon" (Gehman et al., 2018, p. 287) focus on 18 HOs whose operations compete in the global humanitarian relief sector, drawing on interviews and document analysis as data sources. A purposive sampling approach was employed and organisations were selected to represent a range of HOs with different missions, experiences, and viewpoints to gain a better understanding of swift trust and swift distrust against a backdrop of coopetition. As Table 1 shows, the HOs have very different financial means with budgets or income reported in 2018 ranging from under US\$ 100,000 to over US\$ 1billion. Most of the organisations have their headquarters in Europe, with two based in the USA. While some have been operating since the 1940 s, others were founded or registered in the 2010s. The majority have a global orientation, but some focus their efforts on a single country. Their specialisations are diverse, including healthcare, nutrition, refugees etc. HOs were not chosen because of preexisting connections between them, yet because the larger and more established HOs are wellknown across the sector and most interviewees had previously worked with other HOs in the sample, connections quickly became evident. In the interest of anonymity, participants were not asked about connections between them personally, but in the course of the interviews, a few happened to mention other respondents, demonstrating the strong interconnectedness of the sector. Major disaster relief operations in particular (e.g. to the Haiti earthquake in 2010 or the Western African Ebola virus epidemic 2013-2016) had brought together many of the organisations represented in the sample.

$<$ Insert Table 1 here $>$

\subsection{Data collection}

The primary mode of data collection was interviews. Interviews are the most widely employed qualitative research method (Bryman, 2012) and are among the preferred research methods of 
operations management researchers (Larson and Halldórsson, 2004). As with other qualitative techniques, interviews are concerned not with measurement, but with the understanding and collection of rich data (Walker, 1985). The richness of data that can be collected through interviews helps in understanding causal relationships (Aastrup and Halldórsson, 2008), which is essential in addressing our research question. A broad interview guide with semi-structured questions was used as recommended by Bryman (2012) and Easterby-Smith et al. (2012). Departures from this guide were encouraged during the interviews; while there were certain key topics to be covered, a flexible and adaptive interviewing style was used to encourage expression of uninhibited views, thus creating a holistic picture of the context under investigation (Hindle et al., 1995). The aim was to interview actors in a variety of roles within HOs and the interview guide was adapted over time to reflect emergent themes. Questions were structured around themes of strategic and operational decision making, benefits and drawbacks of working with others, the start of such working relationships and their development over time, and the experience of the respondents in humanitarian responses with a focus on uncertainty and interdependence.

In total, 48 interviews were conducted with knowledgeable and experienced respondents from the 18 organisations (see Table 1), thereby fitting the recommended range of 15 to 60 interview participants (Saunders and Townsend, 2016) for theory elaborating research (Ketokivi and Choi, 2014). Interviews were conducted face-to-face, over the telephone, or through voice over IP applications. All interviewees were professionals working within supply chain, logistics, and operations functions for HOs at both field level and headquarters. All respondents had participated in at least one disaster response, but most had experience across several responses. This mixture of respondents with first-hand knowledge and diverse perspectives can help reduce the likelihood of retrospective sensemaking (Eisenhardt and Graebner, 2007). Secondary data, in the form of publicly available information from most of the organisations in the sample (e.g. annual reports, white papers, websites, and partnership material) were used to supplement evidence from the interviews in order to ensure internal validity (Voss et al., 2002, Eisenhardt and Graebner, 2007). These documents were collected by searching the organisations' websites for information pertaining to the ways in which they interact with other organisations. These documents helped to develop a general understanding of the operating processes, collaboration practices and principles, and partnership strategies, thus providing a meso level perspective to contrast with the micro level sensemaking in the interviews (Tidström and Rajala, 2016). The terms collaboration, cooperation, partnership, and coordination were 
often used interchangeably with no clear delineation of their meaning. Therefore, documents pertaining to all of these keywords were included in the analysis. Table 2 provides an overview of data sources from each organisation.

\section{$<$ Insert Table 2 here $>$}

\subsection{Data analysis}

The interviews were recorded and the transcripts were entered into NVivo for data analysis, as recommended by Fielding and Lee (1991) and Kelle et al. (1995). Data analysis was carried out by coding the data, following the recommendations of Corbin and Strauss (2008) and Saldana (2013) whereby a priori codes were extracted from the extant literature, with emergent codes developing during the data analysis. The a priori codes focused on the four areas examined in the literature review: coopetition, uncertainty and interdependence, antecedents of swift trust, and antecedents of swift distrust. Table 3 provides a summary of all a priori and emergent codes with brief descriptions as to the coding protocol for each. As recommended by Miles et al. (2014), we coded each interview multiple times, revisiting the coding to ensure internal consistency. Interview data were compared and contrasted with the publicly available secondary source material where available. This material was analysed using the same process as for the primary data. In this process we identified both agreement and convergence between the officially communicated stance and the individual experiences and opinions of respondents. We went back and forth between data collection and data analysis until no further new insights were forthcoming, indicating that the completeness by redundancy in data collected from further participants implies sufficiency (Safman and Sobal, 2004).

\section{$<$ Insert Table 3 here $>$}

\section{Findings}

Table 4 summarises the themes from the interview data and provides illustrative quotes for each of these. All interviews were conducted in English, making translation unnecessary. However, as English was not the native tongue for all respondents, some idiosyncratic and unusual expressions were used. Where necessary, the interviewer would ask for clarification of a response. Transcription was denaturalised in so far as "idiosyncratic elements of speech (e.g., stutters, pauses, nonverbal, involuntary vocalizations)" were removed (Oliver et al., 2005, pp. 1273-1274) allowing for easier readability of the representative quotes. 


\subsection{Coopetition under conditions of uncertainty and interdependence}

Respondents acknowledge the fiercely competitive environment in which they operate at a time when funding insecurity, particularly over the longer term, is a concern for HOs. Furthermore, HOs compete for beneficiaries, with respondents highlighting that beneficiaries increasingly compare the aid on offer. Simultaneously, it is very important that HOs are seen to be doing good work by the media and other stakeholders, such as national governments. HOs therefore have a keen interest in emphasising their own achievements over those of their competitors. In addition, they compete for goods and services; for example, cargo capacity on flights into areas affected by disaster is usually extremely limited, resulting in increased rates being charged. This example also highlights the strong interdependence between organisations as all of them rely on the same means for shipping their goods, compete in the same market, and ultimately have the same overarching aim. Cooperation occurs simultaneously with competition and is widely acknowledged as a necessity to achieve the overall aim of humanitarian relief; the alleviation of suffering. Particularly among the larger HOs, working with other organisations is highlighted as a common strategic aim or ambition. Respondents suggest that HOs work together in a variety of ways, ranging from formal contractual agreements to ad hoc help provided in difficult situations. Some cooperation is facilitated through mechanisms such as the logistics cluster where organisations come together to exchange information, but much of it is established on an individual, micro level driven by specific circumstances encountered in the field. There is a keen awareness among respondents of the paradox of coopetition and the need to balance organisational priorities with the wider aims of humanitarian work.

Respondents also suggest that the motivations for coopetitive behaviour are often pragmatic as it is impossible (or highly inefficient) for an individual HO to carry out its operations in isolation. The extreme uncertainty of the operating environment necessitates cooperation. For example, the desire to gain access to certain geographical areas and to develop an understanding of them is seen as a powerful driver for seeking out parties to cooperate with. A particularly prominent approach involves cooperation with local HOs who have developed networks and local knowledge over time but often lack the resources and expertise that an international NGO offers. Even HOs and individuals that are more wary of cooperating with competitors highlight the benefits of sharing information in the changeable and often unpredictable environment of humanitarian relief. However, respondents highlight that 
information tends to be gathered separately, then shared, and often interpreted separately as well, with only few instances of joint planning reported. Nevertheless, this shows that some level of cooperation is a common way to manage uncertainty and respondents acknowledge the strong interdependence within the humanitarian system as strengths are pooled. Benefits of collaboration include cost savings and the improved access to key resources which can be scarce in humanitarian responses. As many HOs focus on particular areas of humanitarian aid (e.g. nutrition, sanitation, or shelter) cooperating allows them to build on each other's strengths to provide a comprehensive response to beneficiaries' needs. Increased security is another benefit of cooperating, particularly in war zones like Syria.

While the competitive side of the relationships is widely regarded as enduring (particularly among international NGOs who compete for donations on a global scale) much of the cooperation is seen as context-specific and temporary. Frequently, benefits are clearly defined for a very particular situation, for example the delivery of one shipment or the running of one vaccination campaign, and are not seen in a wider, more permanent context. However, respondents report natural alliances with HOs that have similar mindsets and operating procedures and are therefore drawn to each other again and again in different situations. Such arrangements are formalised to some degree or form part of a HO's strategy, as many are keen to highlight their cooperation with a range of strong partners in their publicly available materials. Duplication of effort is a well-known problem and respondents are keen to use limited resources more efficiently, for example by delivering aid through joint convoys. External pressure also drives cooperation, as donors request evidence of value for money being delivered and increasingly seek to ensure that resources are used to build capacity locally. Respondents report that funding is often tied to working with other HOs, further enhancing interdependence and incentivising coopetitive behaviour. However, respondents state that cooperation also frequently occurs between individuals who have formed a personal connection that may span across humanitarian responses. Such a connection is not necessarily tied to particular HOs but occurs on an individual level and remains constant even as job roles, employers and contexts change. Such personal connections often result in informal cooperation against a background of competition. Cooperation and competition therefore occur simultaneously under conditions of uncertainty and interdependence, while also contributing to the creation of such conditions.

\subsection{Swift trust and swift distrust}


The strong interdependence in the humanitarian sector results in familiarity with other individuals and organisations in any particular disaster response. While some of the coopetitive relationships are strategic, many are built on necessity at the operational level, frequently between field staff of different HOs. In the hastily formed networks of humanitarian relief operations, swift trust is prominent, utilising the peripheral route to developing trust, but due to the familiarity with other actors, the central and habitual routes are also utilised. We find that a common determinant of swift trust is category, where organisations of a certain type are regarded as trustworthy without any direct experience because of a shared organisational type and/or values (e.g. views on neutrality of humanitarian relief). At times, parties enter into a trusting relationship because of a role that they fulfil or because of an external seal of approval. This can be the case when a HO works with the national government. Individuals and organisations acknowledge that there is little certainty within the humanitarian context. For example, respondents report limited reliance on third-party information in the form of official certifications, although an ISO certificate might be desirable to build trust in a commercial supplier. The lack of reliable third-party information is not perceived as a concern by the respondents as it is noted that there is little that HOs can utilise to build trust beyond their personal experience. This strong awareness of uncertainty also helps to build swift trust as a way to manage uncertainty and operate at the necessary speed, and hence in this context swift trust facilitates cooperation.

Features of interdependence can also engender swift distrust. On the meso level, there is distrust between organisations. Category, as per the peripheral route to trust, can trigger swift distrust, most prominently with military actors. Many HOs will not cooperate with the military under any circumstances as this would jeopardise their neutrality, and some have similar aversions towards politically aligned NGOs. We also find governance to be an important facet of swift distrust, including examples of lack of regulation and efficiency. When another disaster occurs, it is often the case that the same group of NGOs will enter into subsequent coopetitive relationships, albeit in a different humanitarian disaster context. We find that whilst trust may develop over time, it is antecedents of swift distrust that emerge very clearly from our data. Swift distrust forms between organisations and at the micro level between individuals, often based on the central and habitual routes comprising perceived ability, perceived integrity and history. We find coopetitive distrust to develop when expectations are not met and a partner does not fulfil their obligations or does not do so to the satisfaction of the other party (e.g. by delivering shipments late or not at all). In a high-pressure environment, such disappointment 
leaves a lasting impression on perceived ability and integrity. Respondents state that they take such distrust towards a certain $\mathrm{HO}$ or an individual forward into future operations and hence history plays an important part in coopetitive relationships. In a sector that brings together many of the same NGOs again and again (and where staff turnover is high) many individuals meet again in different circumstances. Respondents report that experience from previous roles is carried over and informs their decision-making in future questions of whether to trust. Swift distrust does not necessarily need to be perceived by organisations and individuals as negative, nor as a barrier to collaborative practices. Indeed, our findings show how swift distrust helps to manage uncertainty as quick judgements are made about potentially unreliable or risky partners and strategies are implemented to reduce risk (e.g. providing additional training to distrusted partners, building in additional buffers and taking steps to limit reputational damage). Our findings therefore suggest that both swift trust and swift distrust are important in realising the benefits of coopetition, particularly in environments where interdependence and uncertainty are high.

\section{Discussion}

To address the research question: how do swift trust and swift distrust support coopetition under conditions of uncertainty and interdependence? we present important insights and offer theoretical contributions. Overall, our findings suggest that in different ways both swift trust and swift distrust are helpful in enabling organisations operating in a temporary context, such as disaster relief, to engage in coopetition. We therefore propose that swift trust and swift distrust should both be understood as means of facilitating coopetition under conditions of uncertainty and interdependence. Drawing on commitment-trust theory (Morgan and Hunt, 1994), we first discuss the role of swift trust in supporting coopetition in the context of humanitarian operations and different routes to swift trust. Second, we provide insight into swift distrust in terms of its antecedents and the implications for coopetition.

Firstly, we find that swift trust, mainly developed through the peripheral route, plays an important role in enabling coopetition in temporary contexts (i.e. humanitarian operations). We find that swift trust enables coopetition primarily through the antecedents of category and necessity. HOs are able to develop workable relationships with other HOs primarily because these relationships are necessary to deliver complex humanitarian relief outcomes. This finding is in line with previous studies highlighting the role of swift trust in humanitarian logistics (Tatham and Kovács, 2010) and in particular through a commitment to enable coordination 
among humanitarian actors (Dubey et al., 2019a). In addition, our findings also confirm that cooperation and competition can occur simultaneously (Bengtsson and Kock, 2014, Gnyawali et al., 2016) among interdependent HOs in an uncertain operating environment.

In order to further our understanding of the role of swift trust in enabling coopetition, we examined the antecedents of swift trust in the context of disaster relief. Referring to the general framework by Hung et al. (2004) on the peripheral route to swift trust, we find the category of an organisation (for example its type/values) to be an important determinant of swift trust as individuals and organisations almost immediately make decisions about the types of organisations they are willing to collaborate with (i.e. military or government). We found less reliance on utilising third-party information despite its importance in developing trust in humanitarian relief operations (Tatham and Kovács, 2010). This may be partly due to the fact that there are few formal documents, other than the ISO certificates, to help to assess the reputation of an $\mathrm{HO}$ and/or the reputation of its employees. Building on the five antecedents of swift trust developed by Hung et al. (2004), we extend this trust model by offering a new antecedent: necessity, indicating that need is essential to the rapid formation of trust.

Our research finds that in coopetitive relationships, the three routes to swift trust are used simultaneously. This finding has important implications for humanitarian organisations engaging in complex interorganisational coopetitive relationships as they may be required to engage in very different routes to swift trust depending on how well they know their coopetitive partners. Thus, our study supports and extends the work of Kramer (1999) and Hung et al. (2004) to a temporary context with characteristics of interdependence and uncertainty. We anticipate that in developing coopetitive relationships with organisations for which there is no prior knowledge, the peripheral route to swift trust will be most helpful. From the perspective of a $\mathrm{HO}$, for example, this is because some of the individuals and organisations encountered in a new context will be more familiar than others. Yet for those organisations about which knowledge has been accumulated, we expect the central or habitual routes to be more appropriate. Hung et al. (2004) note how the central route to trust requires more cognitive effort, presumably as evaluation and value judgements are required. In addition to simultaneously negotiating three different routes to trust, organisations will also be navigating the coopetitive paradox. We suggest that in complex interorganisational coopetitive relationships, organisations can simultaneously navigate three routes to trust (peripheral, 
central and habitual) whose relative importance depends on context-specific elements, such as recurrent interactions with individuals and organisations as encountered in our research.

Secondly, we explore how swift distrust can help to explain approaches to coopetition in humanitarian operations by showing how swift distrust can aid in managing uncertainty. Prior studies on humanitarian operations have examined the concept of swift trust (Tatham and Kovács, 2010, Lu et al., 2018, Dubey et al., 2019a), yet theory focused explanations that consider swift distrust are under developed. Our attempt to begin to explain the role of swift distrust among humanitarian actors makes an important contribution to this literature. Drawing on the peripheral, central, and habitual routes to trust, we find antecedents to swift distrust to comprise; category, perceived ability, perceived integrity, and history. It is unsurprising that swift distrust is often predicated on previous encounters, particularly concerning perceived ability and integrity at the individual or organisational level. What was surprising was how swift distrust endures, even in contexts that are seemingly temporary. For example, respondents noted how they were reluctant to work with individuals without the requisite skills (e.g. healthcare procedures, logistics and supply chain management, cultural awareness). Such a lack of perceived ability can result in swift distrust, which may have a negative effect on the formation of not only current, but also future coopetitive relationships. These findings demonstrate that the features of interdependence can lead to swift distrust, which is evident at both the individual and organisational level. We also find that swift distrust can enable coopetitive relationships with distrusted partners as it encourages organisations to implement strategies to manage uncertainty and to mitigate risk. In the context of humanitarian relief, we show how HOs working with distrusted partners out of necessity provided additional training, and extended buffers. Such strategies permitted workable relationships to be quickly developed by reducing the uncertainties associated with distrusted partners. In an environment such as humanitarian relief, organisations may not have a choice as to which organisations they work with. Humanitarian relief is recognised as a particularly complex problem with a wide range of diverse actors that come together in changing configurations in each response (Tatham and Houghton, 2011). No HO has control over which other HOs are operating in the same geographical area or doing similar or complementary activities. For speed of response, it is critical that HOs collaborate (Kovács and Spens, 2009). In these types of contexts, we show that swift trust can facilitate cooperation and swift distrust can help with managing uncertainty. Our study, therefore, complements previous studies on the role of swift trust (Tatham and Kovács, 2010, Lu et al., 2018, Dubey et al., 2019a) by including swift distrust. 
Taken together, we advance current theory by showing that swift trust and swift distrust occur simultaneously (Lewicki et al., 1998) and that both swift trust and distrust are effective in different ways in terms of supporting coopetition among HOs. In drawing on swift trust and swift distrust we show how HOs are able to develop workable relationships with other HOs in a context whereby these relationships are necessary to deliver complex humanitarian relief outcomes. Thus, our paper proposes that swift trust and swift distrust can support coopetition under conditions of uncertainty and interdependence. This is an important finding for humanitarian operations in which the same actors may reconvene to work on subsequent disaster relief efforts.

\section{Conclusion}

This study has examined how the concepts of swift trust and swift distrust can be helpful in supporting coopetitive relationships in a temporary nonprofit context by focusing on humanitarian relief operations. We introduce the notion of swift distrust in developing workable interorganisational relationships that rely on trust and commitment between coopetitive partners. We show how swift distrust can encourage coopetitive partners to develop risk mitigation strategies, thus ensuring that distrusting relationships do not preclude the achievement of interorganisational outcomes (in this case, humanitarian relief). As with the simultaneous nature of coopetition, we find that swift trust and swift distrust may simultaneously facilitate cooperation and help with managing uncertainty in hastily formed networks of organisations.

Our study also offers important practical contributions. Individuals working on the ground in humanitarian relief operations are well aware of the need for developing collaborative practices with a wide variety of different types of organisations in order to achieve the shared goal of alleviating suffering. Our study offers a new perspective in how such relationships may be formed. Whilst the utility of swift trust in humanitarian relief organisations is widely acknowledged (Tatham and Kovács, 2010, Dubey et al., 2018, Lu et al., 2018, Dubey et al., 2019a, Dubey et al., 2019b), how swift distrust may help in forming workable relationships with organisations that are distrusted has not been examined in any detail in studies on humanitarian operations. We illustrate how the presence of swift trust and swift distrust enables a better utilisation of scarce resources to achieve overarching humanitarian aims. Both swift trust and swift distrust should be encouraged as they facilitate coopetition by aiding rapid 
decision making under conditions of uncertainty and expediting the development of interorganisational relationships that utilise the high interdependence of the humanitarian system. In practice, HOs can benefit from a clear organisational stance on coopetition (e.g. which types of organisations they are willing to cooperate with), but also from the knowledge and experience of individuals who are familiar with other actors and thus able to make swift trust/distrust decisions more easily. Fostering such personal connections can be beneficial given the strong interdependence of HOs and the necessity for cooperation in competitive contexts. A focus on the simultaneous occurrence of swift trust and swift distrust may improve the speed of network formation which is critical to the humanitarian relief context. Furthermore, we offer insights for managers in commercial supply chains who are in crisis management mode (Dubey et al., 2019a), as our findings indicate the importance of both swift trust and swift distrust in forging interorganisational relationships in times of uncertainty.

Our study is not without limitations. Firstly, we focus only on HOs and do not include additional stakeholders such as the military, governments and beneficiaries. Our focus on HOs was deliberate as it enabled us to capture focused rich data on humanitarian operations from the perspective of individuals delivering humanitarian relief on an international scale, however we acknowledge that we therefore report on a limited stakeholder perspective. Further work that includes multiple stakeholder groups would be a logical focus for subsequent studies. Secondly, our study focused on the context of the humanitarian relief sector as the setting for an examination of temporary networks. Obtaining real world data in the field of humanitarian operations is notoriously difficult (Gupta et al., 2016) and although we have utilised a multiple case study design we acknowledge that the number of cases and interviewees is relatively small. Research that builds on the findings developed in this study could employ quantitative methods across a larger dataset and/or adopt a longitudinal approach to examine swift trust and swift distrust in the context of how coopetitive relationships evolve. Further work may also consider opportunism in developing swift trust and whether initial swift trust may turn to swift distrust. The theoretical and practical relevance of our findings is not restricted to humanitarian operations, and we encourage scholars to extend our work to a variety of contexts in which coopetition is evident. We find the temporary coopetitive setting particularly interesting and would suggest coopetition in contexts including construction projects, academic research and management consulting to be environments in which swift distrust may endure and potentially impact on outcomes. Examining coopetitive distrust in different contexts would further develop the theoretical and practical insights from this study. 


\section{References}

Aastrup, J. \& Halldórsson, Á., (2008), "Epistemological role of case studies in logistics: A critical realist perspective", International Journal of Physical Distribution \& Logistics Management, Vol. 38 No. 10, pp. 746-763. 10.1108/09600030810926475

Adler, T.R., (2005), "The swift trust partnership: A project management exercise investigating the effects of trust and distrust in outsourcing relationships", Journal of Management Education, Vol. 29 No. 5, pp. 714-737. 10.1177/1052562905277304

Adler, T.R., (2007), "Swift trust and distrust in strategic partnering relationships: Key considerations of team-based designs", Journal of Business Strategies, Vol. 24 No. 2, pp. $105-121$.

Altay, N. \& Pal, R., (2014), "Information diffusion among agents: Implications for humanitarian operations", Production and Operations Management, Vol. 23 No. 6, pp. 1015-1027. 10.1111/poms.12102

Austin, J.E. \& Seitanidi, M.M., (2012), "Collaborative value creation: A review of partnering between nonprofits and businesses. Part 1: Value creation spectrum and collaboration stages", Nonprofit and Voluntary Sector Quarterly, Vol. 41 No. 5, pp. 726-758. $10.1177 / 0899764012450777$

Bakshi, N. \& Kleindorfer, P., (2009), "Co-opetition and Investment for Supply-Chain Resilience", Production and Operations Management, Vol. 18 No. 6, pp. 583-603. 10.3401/poms.1080.01031

Balcik, B., Beamon, B.M., Krejci, C.C., Muramatsu, K.M. \& Ramirez, M., (2010), "Coordination in humanitarian relief chains: Practices, challenges and opportunities", International Journal of Production Economics, Vol. 126 No. 1, pp. 22-34. 10.1016/j.ijpe.2009.09.008

Bansal, P., Smith, W.K. \& Vaara, E., (2018), "New ways of seeing through qualitative research", Academy of Management Journal, Vol. 61 No. 4, pp. 1189-1195. 10.5465/amj.2018.4004

Bengtsson, M. \& Kock, S., (2000), "Coopetition in business networks - to co-operate and compete simultaneously", Industrial Marketing Management, Vol. 29 No. 5, pp. 411426. 10.1016/S0019-8501(99)00067-X

Bengtsson, M. \& Kock, S., (2014), "Coopetition - Quo vadis? Past accomplishments and future challenges", Industrial Marketing Management, Vol. 43 No. 2, pp. 180-188. 10.1016/j.indmarman.2014.02.015

Best, B., Moffett, S., Hannibal, C. \& Mcadam, R., (2018), "Examining networked NGO services: reconceptualising value co-creation", International Journal of Operations \& Production Management, Vol. 38 No. 7, pp. 1540-1561. 10.1108/IJOPM-10-20150644

Bleeke, J. \& Ernst, D., (1993), Collaborating to compete John Wiley and Sons Inc: New York. Blomqvist, K. \& Cook, K.S., (2018), Swift Trust - State-of-the-Art and Future Research Directions In R.H. Searle, A. Nienaber \& S. Sitkin (eds.) Routledge Companion to Trust. Routledge: London.

Brandenburger, A.M. \& Nalebuff, A.M., (1996), Co-opetition Currency/Doubleday: New York, USA.

Brewer, M.B., (1981), Ethnocentrism and its role in interpersonal trust. In M.B. Brewer \& B.E. Collins (eds.) Scientific Inquiry and the Social Sciences. Jossey-Bass: New York, 345359.

Bryman, A., (2012), Social research methods, 4th ed. Oxford University Press: Oxford. 
Cavdur, F., Kose-Kucuk, M. \& Sebatli, A., (2016), "Allocation of temporary disaster response facilities under demand uncertainty: An earthquake case study", International Journal of Disaster Risk Reduction, Vol. 19 No. 2016, pp. 159-166. 10.1016/j.ijdrr.2016.08.009

Corbin, J. \& Strauss, A., (2008), Basics of qualitative research : techniques and procedures for developing grounded theory Sage Publications Inc: Thousand Oaks, CA.

Czernek, K. \& Czakon, W., (2016), "Trust building processes in tourist coopetition: The case of a Polish region", Tourism Management, Vol. 52 No. 2016, pp. 380-394. 10.1016/j.tourman.2015.07.009

De Ruyter, K., Moorman, L. \& Lemmink, J., (2001), "Antecedents of commitment and trust in customer-supplier relationships in high technology markets", Industrial Marketing Management, Vol. 30 No. 3, pp. 271-286. 10.1016/S0019-8501(99)00091-7

Denning, P.J., (2006), "Hastily formed networks", Communications of the ACM, Vol. 49 No. 4, pp. 15-20.

Deutsch, M., (1958), "Trust and suspicion", Journal of Conflict Resolution, Vol. 2 No. 4, pp. 265-279. 10.1177/002200275800200401

Dolinskaya, I.S., Shi, Z., Smilowitz, K. \& Ross, M., (2011), Decentralized approaches to logistics co-ordination in humanitarian relief. In T. Doolen \& E. Van Aken (eds.) Proceedings of the 2011 industrial engineering conferences. Reno, NV, no page numbers.

Dubey, R., Altay, N. \& Blome, C., (2019a), "Swift trust and commitment: The missing links for humanitarian supply chain co-ordination?", Annals of Operations Research, Vol. 283 No. 2019, pp. 159-177. 10.1007/s10479-017-2676-z

Dubey, R., Gunasekaran, A., Childe, S.J., Roubaud, D., Fosso Wamba, S., Giannakis, M. \& Foropon, C., (2019b), "Big data analytics and organisational culture as complements to swift trust and collaborative performance in the humanitarian supply chain", International Journal of Production Economics, Vol. 210 No. 2019, pp. 120-136. 10.1016/j.ijpe.2019.01.023

Dubey, R., Luo, Z., Gunasekaran, A., Akter, S., Hanzen, B.T. \& Douglas, M.A., (2018), "Big data and predictive analytics in humanitarian supply chains: Enabling visibility and coordination in the presence of swift trust", The International Journal of Logistics Management, Vol. 29 No. 2, pp. 485-512. 10.1108/IJLM-02-2017-0039

Easterby-Smith, M., Thorpe, R. \& Jackson, P., (2012), Management Research, 4th ed. Sage: Los Angeles, CA.

Easton, G., (2010), "Critical realism in case study research", Industrial Marketing Management, Vol. 39 No. 1, pp. 118-128. 10.1016/j.indmarman.2008.06.004

Eisenhardt, K.M. \& Graebner, M.E., (2007), "Theory Building from Cases: Opportunities and Challenges", Academy of Management Journal, Vol. 50 No. 1, pp. 25-32. 10.5465/AMJ.2007.24160888

Fawcett, A.M. \& Fawcett, S.E., (2013), "Benchmarking the state of humanitarian aid and disaster relief - A systems design perspective and research agenda", Benchmarking: An International Journal, Vol. 20 No. 5, pp. 661-692. 10.1108/BIJ-07-2011-0053

Fein, S., (1996), "Effects of suspicion on attributional thinking and the correspondence bias", Journal of Personality and Social Psychology, Vol. 76 No. 6, pp. 1164-1184. 10.1037/0022-3514.70.6.1164

Fernandes, A., Spring, M. \& Tarafdar, M., (2018), "Coordination in temporary organisations: Formal and informal mechanisms at the 2016 Olympics", International Journal of Operations and Production Management, Vol. 38 No. 6, pp. 1340-1367. 10.1108/IJOPM-02-2017-0097

Fielding, N. \& Lee, R.M., (1991), Using Computers in Qualitative Research Sage: London. 
Gehman, J., Glaser, V.L., Eisenhardt, K.M., Gioia, D., Langley, A. \& Corley, K.G., (2018), "Finding Theory-Method Fit: A Comparison of Three Qualitative Approaches to Theory Building", Journal of Management Inquiry, Vol. 27 No. 3, pp. 284-300. $10.1177 / 1056492617706029$

Gnyawali, D.R., Madhavan, R., He, J. \& Bengtsson, M., (2016), "The competiton-cooperation paradox in inter-firm relationships: A conceptual framework", Industrial Marketing Management, Vol. 53 No. 2016, pp. 7-18. 10.1016/j.indmarman.2015.11.014

Gupta, A.K. \& Govindarajan, V., (1999), "Feedback seeking behavior within multinational corporations", Strategic Management Journal, Vol. 20 No. 3, pp. 205-222. $10.1002 / \% 28$ SICI\%2910

Gupta, S., Starr, M., Farahani, R., Matinrad \& N., (2016), "Disaster Management from a POM Perspective: Mapping a New Domain", Production and Operations Management, Vol. 25 No. 10, pp. 1611-1637. 10.1111/poms.12591

Herlin, H. \& Pazirandeh, A., (2012), "Nonprofit organizations shaping the market of supplies", International Journal of Production Economics, Vol. 139 No. 2, pp. 411-421. 10.1016/j.ijpe.2011.04.003

Hindle, T., Checkland, P., Mumford, M. \& Worthington, D., (1995), "Developing a methodology for multidisciplinary action research: A case study", The Journal of the Operational Research Society, Vol. 46 No. 4, pp. 453-464. 10.2307/2584593

Hung, Y.-T.C., Dennis, A.R. \& Robert, L., (2004). Trust in virtual teams: Towards an integrative model of trust formation. Proceedings of the 37th Hawaii Conference on System Sciences.

Jahre, M., Jensen, L.M. \& Listou, T., (2009), "Theory development in humanitarian logistics: a framework and three cases", Management Research News, Vol. 32 No. 11, pp. 10081023. 10.1108/01409170910998255

Johnston, D.A., Mccutcheon, D.M., Stuart, F.I. \& Kerwood, H., (2004), "Effects of supplier trust on performance of cooperative supplier relationships", Journal of Operations Management, Vol. 22 No. 1, pp. 23-38. 10.1016/j.jom.2003.12.001

Kabra, G. \& Ramesh, A., (2015), "Analysing drivers and barriers of coordination in humanitarian supply chain management under fuzzy environment", Benchmarking: An International Journal, Vol. 22 No. 4, pp. 559-587. 10.1108/BIJ-05-2014-0041

Kelle, U., Prein, G. \& Bird, K., (1995), Computer-Aided Qualitative Data Analysis: Theory, Methods and Practice Sage: London.

Ketokivi, M. \& Choi, T., (2014), "Renaissance of case research as a scientific method", Journal of Operations Management, Vol. 32 No. 5, pp. 232-240. 10.1016/j.jom.2014.03.004

Kostis, A. \& Näsholm, M.H., (in press), "Towards a research agenda on how, when and why trust and distrust matter to coopetition", Journal of Trust Research, Vol. No. $10.1080 / 21515581.2019 .1692664$

Kovács, G. \& Spens, K., (2008), Humanitarian logistics revisited. In J. Stentoft Arlbjorn, A. Halldórsson, M. Jahre \& K. Spens (eds.) Northern Lights in Logistics and Supply Chain Management. Copenhagen Business School Press: Copenhagen, 217-232.

Kovács, G. \& Spens, K., (2009), "Identifying challenges in humanitarian logistics", International Journal of Physical Distribution \& Logistics Management, Vol. 39 No. 6, pp. 506-528. 10.1108/09600030910985848

Kovács, G. \& Spens, K.M., (2007), "Humanitarian logistics in disaster relief operations", International Journal of Physical Distribution \& Logistics Management, Vol. 37 No. 2, pp. 99-114. 10.1108/09600030710734820

Kramer, R.M., (1999), "Trust and distrust in organisations: Emerging perspectives, enduring questions", Annual Review of Psychology, Vol. 50 No. 1, pp. 569-598. 10.1146/annurev.psych.50.1.569 
Krishnan, R., Martin, X. \& Noorderhaven, N.G., (2006), "When Does Trust Matter to Alliance Performance?", Academy of Management Journal, Vol. 49 No. 5, pp. 894-917. 10.5465/amj.2006.22798171

Lado, A.A., Boyd, N.G. \& Hanlon, S.C., (1997), "Competition, cooperation, and the search for economic rents: A syncretic model", Academy of Management Review, Vol. 22 No. 1, pp. 110-141. 10.2307/259226

Larson, P.D. \& Halldórsson, A., (2004), "Logistics versus supply chain management: an international survey", International Journal of Logistics: Research and Applications, Vol. 7 No. 1, pp. 17-31. 10.1080/13675560310001619240

Le Roy, F. \& Czakon, W., (2016), "Managing coopetition: The missing link between strategy and performance", Industrial Marketing Management, Vol. 52 No. no issue number, pp. 3-6. 10.1016/j.indmarman.2015.11.005

Lewicki, R.J., Mcallister, D.J. \& Bies, R.J., (1998), "Trust and distrust: New relationships and realities", Academy of Management Review, Vol. 23 No. 3, pp. 438-458. $10.2307 / 259288$

Li, P.P., (2017), "The time from transition: Future trust research", Journal of Trust Research, Vol. 7 No. 1, pp. 1-14. 10.1080/21515581.2017.1293772

Liu, R., (2013), "Cooperation, competition and coopetition in innovation communities", Prometheus, Vol. 31 No. 2, pp. 91-105. 10.1080/08109028.2013.818788

Lu, Q., Goh, M. \& De Souza, R., (2018), "An empirical investigation of swift trust in humanitarian logistics operations", Journal of Humanitarian Logistics and Supply Chain Management, Vol. 8 No. 1, pp. 70-86. 10.1108/Jhlscm-07-2017-0033

Mayer, R.C., Davis, J.H. \& Schoorman, F.D., (1995), "An Integrative Model of Organizational Trust", Academy of Management Review, Vol. 20 No. 3, pp. 709-734. 10.5465/amr.1995.9508080335

Mcevily, B., Perrone, V. \& Zaheer, A., (2003), "Trust as an organising principle", Organisation Science, Vol. 14 No. 1, pp. 91-103. 10.1287/orsc.14.1.91.12814

Mclachlin, R. \& Larson, P.D., (2011), "Building humanitarian supply chain relationships: lessons from leading practitioners", Journal of Humanitarian Logistics \& Supply Chain Management, Vol. 1 No. 1, pp. 32-49. 10.1108/20426741111122402

Meyerson, D., Weick, K.E. \& Kramer, R.M., (1996), Swift Trust and Temporary Groups. In R.M. Kramer \& T.R. Tyler (eds.) Trust in Organizations: Frontiers of Theory and Research. Sage Publications: Thousand Oaks, CA, 166-195.

Miles, M.B., Huberman, A.M. \& Saldana, J., (2014), Qualitative Data Analysis: A Methods Sourcebook Sage: Thousand Oaks, CA.

Mohr, J. \& Speckman, R., (1994), "Characteristics of partnership success: Partnership attributes, communication behaviour, and conflict resolution techniques", Strategic Management Journal, Vol. 15 No. 2, pp. 135-142. 10.1002/smj.4250150205

Morgan, R.M. \& Hunt, S.D., (1994), "The commitment-trust theory of relationship marketing", Journal of Marketing, Vol. 58 No. 1994, pp. 20-38. 10.2307/1252308

Moshtari, M., (2016), "Inter-organisational fit, relationship management capability, and collaborative performance within a humanitarian setting", Production and Operations Management, Vol. 25 No. 9, pp. 1542-1557. 10.1111/poms.12568

Nielsen, B.B. \& Nielsen, S., (2009), "Learning and innovation in international strategic alliances: An empirical test of the role of trust and tacitness", Journal of Management Studies, Vol. 46 No. 6, pp. 1031-1056. 10.1111/j.1467-6486.2009.00840.x

Oliver, D.G., Serovich, J.M. \& Mason, T.L., (2005), "Constraints and opportunities with interview transcription: Towards reflection in qualitative research", Social Forces, Vol. 84 No. 2, pp. 1273-1289. 10.1353/sof.2006.0023 
Oloruntoba, R. \& Gray, R., (2006), "Humanitarian aid: an agile supply chain?", Supply Chain Management, Vol. 11 No. 2, pp. 115-126. 10.1108/13598540610652492

Olsen, O.K., (2018), Effective Cooperation Between Strangers in Unexpected and Dangerous Situations - A Matter of "Swift Trust". In G.E. Torgersen (ed.) Interaction: 'Samhandling' Under Risk. A Step Ahead of the Unforeseen. Cappelen Damm Akademisk: Oslo, 399-412.

Parkhe, A., (1993), "Alliance structuring: A game theoretic and transaction cost examination of interfirm cooperation", Academy of Management Journal, Vol. 36 No. 4, pp. 794829. $10.2307 / 256759$

Patzelt, H. \& Shepherd, D.A., (2008), "The decision to persist with underperforming alliances", Journal of Management Studies, Vol. 45 No. 7, pp. 1217-1243. 10.1111/j.14676486.2008.00791.x

Ritala, P., (2012), "Coopetition strategy - when is it successful? Empirical evidence on innovation and market performance", British Journal of Management, Vol. 23 No. 3, pp. 307-324. 10.1111/j.1467-8551.2011.00741.x

Safman, R.M. \& Sobal, J., (2004), "Qualitative Sample Extensiveness in Health Education Research", Health Education \& Behavior, Vol. 31 No. 1, pp. 9-21. $10.1177 / 1090198103259185$

Saldana, J., (2013), The Coding Manual for Qualitative Researchers, 2nd ed. SAGE: Los Angeles, CA; London.

Saunders, M.N.K. \& Townsend, K., (2016), "Reporting and Justifying the Number of Interview Participants in Organization and Workplace Research", British Journal of Management, Vol. 27 No. 4, pp. 836-852. 10.1111/1467-8551.12182

Saxton, T., (1997), "The effects of partner and relationship characteristics on alliance outcomes", Academy of Management Journal, Vol. 40 No. 2, pp. 443-461. $10.2307 / 256890$

Schulz, S.F. \& Blecken, A., (2010), "Horizontal cooperation in disaster relief logistics: Benefits and impediments", International Journal of Physical Distribution \& Logistics Management, Vol. 40 No. 8, pp. 636-656. 10.1108/09600031011079300

Skinner, D., Dietz, G. \& Weibel, A., (2014), "The dark side of trust: When trust becomes a 'poisoned chalice"', Organisation, Vol. 21 No. 2, pp. 206-224. $10.1177 / 1350508412473866$

Tatham, P. \& Houghton, L., (2011), "The wicked problem of humanitarian logistics and disaster relief aid", Journal of Humanitarian Logistics \& Supply Chain Management, Vol. 1 No. 1, pp. 15-31. 10.1108/20426741111122394

Tatham, P. \& Kovács, G., (2010), "The application of "swift trust" to humanitarian logistics", International Journal of Production Economics, Vol. 126 No. 1, pp. 35-45. 10.1016/j.ijpe.2009.10.006

Tidström, A. \& Rajala, A., (2016), "Coopetition strategy as interrelated praxis and practices on multiple levels", Industrial Marketing Management, Vol. 58 No. 2016, pp. 35-44. 10.1016/j.indmarman.2016.05.013

Tsai, W., (2002), "Social Structure of "Coopetition" within a Multiunit Organization: Coordination, Competition, and Intraorganizational Knowledge Sharing", Organisation Science, Vol. 13 No. 2, pp. 179-190. 10.1287/orsc.13.2.179.536

Van Wassenhove, L.N., (2006), "Blackett Memorial Lecture - Humanitarian aid logistics: supply chain management in high gear", Journal of the Operational Research Society, Vol. 57 No. 5, pp. 475-489. 10.1057/palgrave.jors.2602125.

Voss, C., Johnson, M. \& Godsell, J., (2016), Case research. In C. Karlsson (ed.) Research Methods for Operations Management. 2nd ed. Routledge: New York, NY, 165-197. 
Voss, C., Tsikriktsis, N. \& Frohlich, M., (2002), "Case research in operations management", International Journal of Operations and Production Management, Vol. 22 No. 2, pp. 195-219. 10.1108/01443570210414329

Wakolbinger, T., Fabian, F. \& Kettinger, W., (2013), "IT-enabled Interorganizational Information Sharing Under Co-opetition in Disasters: A Game-Theoretic Framework", Communications of the Association for Information Systems, Vol. 33 No. October 2013, pp. 67-80. 10.17705/1CAIS.03305

Walker, R., (1985), Applied Qualitative Research Gower Publishing Company Limited: Aldershot.

Zaheer, A., Mcevily, B. \& Perrone, V., (1998), "Does trust matter? Exploring the effects of interorganisational and interpersonal trust on performance", Organisation Science, Vol. 9 No. 2, pp. 141-159. 10.1287/orsc.9.2.141 
Table 1: Description of Organisations

\begin{tabular}{|c|c|c|c|c|}
\hline Organisation & Headquarters in & $\begin{array}{l}\text { Registered/ } \\
\text { Founded in }\end{array}$ & Focus / Specialisation & $\begin{array}{l}\text { Income/Budget in } 2018 \\
\text { in USS }\end{array}$ \\
\hline A & USA & 1987 & Healthcare, global & 101-200 million \\
\hline $\mathrm{B}$ & UK & 1942 & Poverty, global & 501-600 million \\
\hline $\mathrm{C}$ & Netherlands & 1984 & Healthcare, global & $301-400$ million \\
\hline $\mathrm{D}$ & UK & 2000 & Disasters, global & $1-10$ million \\
\hline $\mathrm{E}$ & France & 1971 & Healthcare, global & $401-500$ million \\
\hline $\mathrm{F}$ & UK & 1992 & Poverty, single country & under 100,000 \\
\hline $\mathrm{G}$ & UK & 1993 & Nutrition, global & 11-100 million \\
\hline $\mathrm{H}$ & Switzerland & 1948 & Healthcare, global & over 1 billion \\
\hline $\mathrm{I}$ & Italy & 1961 & Nutrition, global & over 1 billion \\
\hline $\mathrm{J}$ & UK & 1997 & Disasters, global & 101-200 million \\
\hline $\mathrm{K}$ & Ireland & 2012 & Supply, single country & under 100,000 \\
\hline $\mathrm{L}$ & UK & 1997 & Development, global & over 1 billion \\
\hline $\mathrm{M}$ & Denmark & 1956 & Refugees, global & $401-500$ million \\
\hline $\mathrm{N}$ & Germany & 1950 & Supply, global & 201-300 million \\
\hline $\mathrm{O}$ & UK & 1999 & Disasters, global & under 100,000 \\
\hline $\mathrm{P}$ & UK & 2011 & Nutrition, single country & $100,000-1$ million \\
\hline Q & USA & 1946 & Children, global & over 1 billion \\
\hline $\mathrm{R}$ & UK & 1997 & Supply, global & $1-10$ million \\
\hline
\end{tabular}


Table 2: Data sources

\begin{tabular}{|c|c|c|}
\hline Organisation & Interviewee mnemonics (gender, field/headquarter level) & $\begin{array}{l}\text { Material analysed (e.g. annual reports, white papers, websites, company } \\
\text { and partnership material) }\end{array}$ \\
\hline A & A1 (male, field) & $\begin{array}{l}\text { Dedicated partnership section on website with detailed instructions and } \\
\text { reports }\end{array}$ \\
\hline $\mathrm{B}$ & B1 (male, headquarters), B2 (male, headquarters), B3 (male, headquarters) & Partnership guidelines, detailed descriptions of processes, toolkits, blog posts \\
\hline $\mathrm{C}$ & $\begin{array}{l}\text { C1 (male, headquarters), C2 (male, headquarters), C3 (male, headquarters), } \\
\text { C4 (male, field) }\end{array}$ & $\begin{array}{l}\text { Values and guidelines, reports on individual partnerships and collaborations, } \\
\text { sections in mission reports }\end{array}$ \\
\hline $\mathrm{D}$ & D1 (male, headquarters), D2 (male, headquarters), D3 (male, headquarters) & Brief mention of working together to achieve organisational mission \\
\hline $\mathrm{E}$ & $\begin{array}{l}\text { E1 (male, field), E2 (male, headquarters), E3 (female, field), E4 (male, } \\
\text { headquarters), E5 (female, field), E6 (female, field), E7 (male, field), E8 } \\
\text { (male, field), E9 (female, field), E10 (female, field) }\end{array}$ & $\begin{array}{l}\text { Detailed reports on partnerships and collaborations in different contexts, } \\
\text { critical analysis in mission reports }\end{array}$ \\
\hline $\mathrm{F}$ & F1 (female, headquarters) & No relevant material publicly available \\
\hline $\mathrm{G}$ & G1 (female, headquarters), G2 (female, headquarters) & No relevant material publicly available \\
\hline $\mathrm{H}$ & $\begin{array}{l}\text { H1 (male, headquarters), H2 (male, headquarters), H3 (male, headquarters), } \\
\text { H4 (male, field) }\end{array}$ & $\begin{array}{l}\text { Dedicated collaborations section on website with detailed instructions and } \\
\text { reports }\end{array}$ \\
\hline I & I1 (female, field), I2 (male, field), I3 (male, field), I4 (female, field) & $\begin{array}{l}\text { Dedicated collaborations section on website, partnership strategy document, } \\
\text { major emphasis in strategic plan }\end{array}$ \\
\hline $\mathrm{J}$ & J1 (female, field), J2 (female, field), J3 (female, field) & $\begin{array}{l}\text { Focus on collaboration in annual report, resources on partnerships and } \\
\text { collaborations }\end{array}$ \\
\hline $\mathrm{K}$ & K1 (male, field), K2 (male, field) & No relevant material publicly available \\
\hline $\mathrm{L}$ & $\begin{array}{l}\text { L1 (male, headquarters), L2 (male, headquarters), L3 (male, headquarters), } \\
\text { L4 (male, headquarters) }\end{array}$ & $\begin{array}{l}\text { Clear rules and processes for working together, report on current } \\
\text { partnerships }\end{array}$ \\
\hline $\mathrm{M}$ & M1 (male, field) & Sets out standards for collaboration, mentioned in operational principles \\
\hline $\mathrm{N}$ & N1 (male, field) & Discussed in annual report \\
\hline $\mathrm{O}$ & O1 (male, headquarters), O2 (male, headquarters) & No relevant material publicly available \\
\hline $\mathrm{P}$ & P1 (male, field) & No relevant material publicly available \\
\hline Q & Q1 (male, field) & $\begin{array}{l}\text { News items on partnerships, dedicated section on website, several examples } \\
\text { in annual report, focus in strategic plan, }\end{array}$ \\
\hline $\mathrm{R}$ & R1 (female, headquarters) & Dedicated research papers, coordination highlighted as key topic on website \\
\hline
\end{tabular}




\begin{tabular}{|c|c|}
\hline \multicolumn{2}{|l|}{ CODING CATEGORY } \\
\hline Coopetition & \\
\hline - Competition & $\begin{array}{l}\text { - Instances of competing with other HOs for goods, services, finances, information, or access to beneficiaries; operating in } \\
\text { and adapting to a competitive environment }\end{array}$ \\
\hline - Cooperation & $\begin{array}{l}\text { - Instances of working together with other HOs both in the short and long term; sharing goods, services, finance, information, } \\
\text { or access to beneficiaries }\end{array}$ \\
\hline - Coopetition & - Instances of simultaneous cooperation and competition between HOs \\
\hline - Motivations & $\begin{array}{l}\text { - Instances of coopetition being motivated by increased efficiency, improvements to the competitive position, creation of } \\
\text { new markets etc. }\end{array}$ \\
\hline - Benefits & - Instances of benefits arising from coopetition, such as cost savings, increased resilience etc. \\
\hline - Local Partners & $\begin{array}{l}\text { - Instances of working with HOs based in the operational environment; utilising local knowledge and local structures; } \\
\text { building capacity }\end{array}$ \\
\hline \multicolumn{2}{|l|}{ Uncertainty and Interdependence } \\
\hline - Time pressure & - Instances of operating under time pressure \\
\hline $\begin{array}{l}\text { - High levels of } \\
\text { interdependence }\end{array}$ & - Instances of interdependent tasks; interacting with a great number and variety of actors \\
\hline - Need for rapid action & $\begin{array}{l}\text { - Instances of pressure to respond quickly; desire to respond quickly; changes in the environment necessitating rapid } \\
\text { response }\end{array}$ \\
\hline $\begin{array}{l}\text { - On-the-spot decision } \\
\text { making }\end{array}$ & $\begin{array}{l}\text { - Instances of decentralised decision making; making decisions based on incomplete information; emerging non- } \\
\text { standardised solutions }\end{array}$ \\
\hline \multicolumn{2}{|l|}{ Swift trust antecedents } \\
\hline $\begin{array}{l}\text { - Third-Party Information } \\
\text { - Dispositional Trust }\end{array}$ & $\begin{array}{l}\text { - Instances of trust based on prior reputation and information obtained from parties other than the truster and trustee } \\
\text { Instances of trust because of a general disposition to trust people }\end{array}$ \\
\hline - Rule & $\begin{array}{l}\text { - Instances of trust based on explicit and tacit understandings regarding transactional norms, interactional routines and } \\
\text { exchange practices }\end{array}$ \\
\hline Category & - Instances of trust based on HOs belonging to certain categories with perceived abilities and points of views \\
\hline - Role & $\begin{array}{l}\text { - Instances of trust based on the fact that an } \mathrm{HO} \text { is fulfilling a particular role rather than through specific knowledge about } \\
\text { their competence, motives etc. }\end{array}$ \\
\hline History- & - Instances of trust based on prior positive experiences with the particular HO \\
\hline Necessity & $\begin{array}{l}\text { - Instances of trust because the situation forces HOs to trust each other; a situation arises in which HOs can trust each other } \\
\text { and this is not questioned further }\end{array}$ \\
\hline $\begin{array}{l}\text { Swift distrust antecedents } \\
\qquad \quad \text { Category }\end{array}$ & $\begin{array}{l}\text { - Instances of coopetitive distrust based on HOs belonging to certain categories with perceived limitations and points of } \\
\text { views }\end{array}$ \\
\hline $\begin{array}{l}\text { - } \quad \text { Perceived integrity } \\
\text { - }\end{array}$ & $\begin{array}{l}\text { - Instances of coopetitive distrust based on a perceived lack of integrity of individuals and/or HOs } \\
\text { - Instances of coopetitive distrust based on a perceived lack of competence in an HO }\end{array}$ \\
\hline
\end{tabular}


- Governance

- History-based
- Instances of coopetitive distrust because of a lack of third-party information available on an HO or a perceived lack of coordination from third parties

- Instances of coopetitive distrust based on prior negative experiences with the particular HO or with a particular person or people at an $\mathrm{HO}$ 
Table 4: Coding Categories and Representative Quotes

\begin{tabular}{|c|c|}
\hline Coding Category & Themes and Representative Quotes \\
\hline \multicolumn{2}{|l|}{ Coopetition } \\
\hline - Competition & $\begin{array}{l}\text { Publicity / Media Attention / Image: "Unfortunately, you have to say that it is quite a big competition. Organisations don't worry so much about } \\
\text { resilience or stakeholders, they just want to get their flag on the ground." (J3) } \\
\text { Donations: "the current way that the system is structured with funding, organisations seek funding from the same donors at the same time, at these } \\
\text { kind of critical moments and so there is obviously competition" (R1) } \\
\text { Commercial issues: "there's a lack in logistic services capacity. So, that normally generates a lot of competition between HOs, because we have a } \\
\text { lack of trucks, lack of appropriate warehouses, lack in infrastructure, lack in a seaport with a high capacity, so each one tries to do their best in } \\
\text { these hard circumstances, so it's natural to generate competition between all the parties" (Q1) } \\
\text { Duplication of efforts/ Beneficiaries: "World Food Programme was giving a specific flour, like manioc flour, and the refugees didn't like it. So, } \\
\text { they would just come to us. And we would be like, sure, come to us, without saying, okay, no, I mean, WFP, maybe you need to change this and } \\
\text { that, or let's collaborate. So, yeah, there seems to be this constant competition" (C4) }\end{array}$ \\
\hline - $\quad$ Cooperation & $\begin{array}{l}\text { Informal: "We do it unofficially on the ground. You know, we have the boats, right? So somebody needs to go somewhere in a flooded area and } \\
\text { we get them there, right? But you don't plan it, no. It happens. You just do your work." (N1) } \\
\text { Strategic: "we have the same goals; we are working in the same operation, we are working in the same circumstances, so we must work together } \\
\text { to optimise our goals, because we have the same goals, to serve beneficiaries, in different terms, of course" (Q1) }\end{array}$ \\
\hline - Coopetition & $\begin{array}{l}\text { Spontaneous: "Like, you would help out in an emergency, but really, the focus is on our own projects." (E5) } \\
\text { Strategic: "I was just talking yesterday to implement here in Nigeria, something we implemented in Congo, which is a very basic, simple tool that } \\
\text { will allow you to, in real-time, share your stock levels with different organisations. So, okay, I had pre-ruptures, or stock outs, I will have things } \\
\text { expiring in the next few months. I have overstocks, who wants to take them?" (C4) } \\
\text { Systemic: "if I know I've not got a lot of actors working in a particular response, and they're all from the same sector, then is it better to have two } \\
\text { that have done a hugely strong job, and } 10 \text { that are just mediocre to crap; or do we want everyone to be slightly better than average by working } \\
\text { together? And you know, I'd rather go for the latter" (L4) }\end{array}$ \\
\hline - $\quad$ Motivations & $\begin{array}{l}\text { New market creation / increasing existent markets: "starting to try this One Health approach, which is, for example cattle in popular nomadic } \\
\text { populations, okay, we wanted to meet the children, and we are partnering with veterinarian organisations that they treat the cattle of the Somali } \\
\text { population. And that's an interesting approach, an interesting partnership to have. It's not like we have... It's not like we're from the same industry } \\
\text { per se, but we have a similar goal, and therefore by partnering together we can have a better outcome." (C4) }\end{array}$ \\
\hline
\end{tabular}




\begin{tabular}{|c|c|}
\hline & $\begin{array}{l}\text { Efficiency in resource utilisation: "we need to pool resources across agencies to achieve cost savings. There is no point in duplicating efforts" (J3) } \\
\text { Improvement in competitive position: "That's important because it makes us bigger and potentially, we can have more impact. That's very } \\
\text { important." (F1) }\end{array}$ \\
\hline - $\quad$ Benefits & $\begin{array}{l}\text { Cost savings: "By working with partners, we will be able to increase our supplier network. That might lead to, A, better lead-times, B, better } \\
\text { quality, but also potentially, pooled procurement might also lead to better pricing" (C4) } \\
\text { Information sharing: "there's general recognition, across the board, that sharing information is helpful and that you need to work with others, in } \\
\text { order to get the latest information that you might not have, whether be about the situation or about technical approaches that have worked or about } \\
\text { how to deal with a certain problem or join together to do some kind of advocacy" (R1) } \\
\text { Access to key resources: "I have a shipment to, let's say, Latakia city and also my colleague in WFP has a shipment to the same destination in } \\
\text { Latakia city. We could do that in cooperation or not. If we don't cooperate, we make competition who could obtain the trucks and do that } \\
\text { shipment. If we cooperate, we could organise shipment and schedule a timetable, and not compete on transportation services." (Q1) } \\
\text { Avoidance of duplication: "Collaborating with each other allows us to avoid duplicating efforts. We get in this position, sometimes an organisation } \\
\text { goes to a specific area, to a specific beneficiary and distributes aid and another organisation knows a beneficiary has severe needs and so they go to } \\
\text { the specific area and give him some cash or a voucher, so the beneficiary, at the end of the day, takes a lot of humanitarian aid, while another } \\
\text { beneficiary doesn't get anything. This is not fair for both of the parties." (Q1) }\end{array}$ \\
\hline - $\quad$ Local Partners & $\begin{array}{l}\text { Local knowledge: "it's all about involving local people. We do that through our local partners and their outreach programmes that really capture a } \\
\text { lot of the community interaction and help us get a lot of feedback on how we do" (O1) } \\
\text { Sustainability: "It can be difficult to set up a project and specially to keep it up in the long term if you don't have the involvement of local people } \\
\text { as well, whether that's community groups, tribes or whatnot. To operate sustainably, you really need the connections on the local level and that } \\
\text { will inform planning as well." (I4) }\end{array}$ \\
\hline \multicolumn{2}{|l|}{$\begin{array}{l}\text { Uncertainty and } \\
\text { Interdependence }\end{array}$} \\
\hline - Time Pressure & $\begin{array}{l}\text { Lack of routine: "There is no routine work. Maybe sometimes when it is quiet, but mainly it is all ad hoc, you just respond to what is } \\
\text { happening around you" (E3) } \\
\text { Cutting corners: "in an emergency, we don't estimate. We just, well we do, but very roughly, we take a lot of what you think you need, and } \\
\text { making an estimate and then sending it" (E6) }\end{array}$ \\
\hline $\begin{array}{ll}\text { - } & \text { High levels of } \\
\text { interdependence }\end{array}$ & $\begin{array}{l}\text { Interacting with diverse actors: "So, we are dealing with, again, international donors; we're dealing with national NGOs; we're dealing with } \\
\text { local characters; we're dealing with Mayors, liaison officers, security advisers. Massive work that is... So lots of network building" (M1) }\end{array}$ \\
\hline
\end{tabular}




\begin{tabular}{|c|c|}
\hline & $\begin{array}{l}\text { Interdependent tasks: "we often interact with the national health system. That can be quite complicated because of bureaucracy. Another } \\
\text { important party on that side are the drugs registration and legislation authorities, we have to work with them" (H1) }\end{array}$ \\
\hline $\begin{array}{l}\text { - Need for rapid } \\
\text { action }\end{array}$ & $\begin{array}{l}\text { Ad hoc responses: "The issues are always ad hoc; you cannot predict that accurately. So it looks like we are doing a lot of firefighting" (J2) } \\
\text { Environmental changes: "it's unpredictable, the environment. Very unstable countries, politically, so that always changes and changes your } \\
\text { supply chain. In that unpredictable mess we work in, we need really agile SCs" (H1) }\end{array}$ \\
\hline $\begin{array}{l}\text { On-the-spot } \\
\text { decision } \\
\text { making }\end{array}$ & $\begin{array}{l}\text { Incomplete information: "It's an uncertain business. We just don't know what's going to happen. Accurate record-keeping is important, but it's } \\
\text { not really a focus. Everyone is there to help the people. The focus is on the patient, not on the records." (E9) } \\
\text { Decentralised decision making: "we had many manuals, but the trouble is that the context is so different every time, so you don't apply a lot of } \\
\text { that. When you are in an emergency situation, you just cannot respect the written down" (H1) } \\
\text { Emergent solutions: "learning to deal with that level of uncertainty and improvise your way through it" (B2) }\end{array}$ \\
\hline \multicolumn{2}{|l|}{ Swift trust antecedents } \\
\hline $\begin{array}{ll}\text { - } & \text { Third-party } \\
\text { information }\end{array}$ & $\begin{array}{l}\text { Donors: "Moving to something a bit more, well, not necessarily cynical, it's generally requirement for funding. Donors will put, "You must go to } \\
\text { the cluster meetings or you must partner with organisations or this funding is for consortium approach," and that sort of thing, so I think a lot of it } \\
\text { is not necessarily by choice, because it's not so much up to them" (R1) } \\
\text { Cluster and Platforms: "We are part of a platform of EU organisations, so some of the planning and initiating is also done centrally through them } \\
\text { and we go along with that" (F1) }\end{array}$ \\
\hline $\begin{array}{l}\text { - } \quad \text { Dispositional } \\
\text { Trust }\end{array}$ & $\begin{array}{l}\text { "We have gained a lot of experience working with people over a number of years, we have really developed these personal connections. They are } \\
\text { very important for us." (\#3) }\end{array}$ \\
\hline Rule & $\begin{array}{l}\text { General rules: "you expect an organisation to kind of behave in the agreed ways of working as part of a humanitarian system by, for example, } \\
\text { following Sphere or following the CHS standards or acting according to humanitarian principles and those sorts of things" (R1) } \\
\text { Memorandum of understanding: "We develop trust between another partner by making your agreement with clear clauses. It's working to sit } \\
\text { around the table to discuss a matter clearly, to appear why do this project or why do this agreement or why we work together, make an agreement } \\
\text { with clear terms and clear clauses, so that everyone knows their role, everyone benefits from this agreement, no one is harmed by the agreement, } \\
\text { no one could leave this agreement and go away." (Q1) }\end{array}$ \\
\hline - Category & $\begin{array}{l}\text { Type of organisation: "I think it's first and foremost about commitment to a common cause and the willingness and ability to put a lot in. As we } \\
\text { are a Christian organisation, we are also looking for people who share those same values, like-minded people are important for us" (P1) } \\
\text { Values of the organisation: "We work with all sorts of different people, as long as they have a vision that aligns with ours, that's great" (P1) }\end{array}$ \\
\hline
\end{tabular}




\begin{tabular}{|c|c|}
\hline - $\quad$ Role & $\begin{array}{l}\text { Role in community: "In that region, the church is like the local newspaper. They do announcements before church. There is no media available, so } \\
\text { that's really the only way to communicate with the entire community. Before the church service, they first announce the date so people know that } \\
\text { and then they announce anything that is new. Through the church we also have a good network and can do a lot of the training locally." (P1) } \\
\text { Role in sector: "In a flooding situation, where you might be more focused on WASH you'd be looking to UNICEF or Oxfam. But if you're } \\
\text { looking to Mozambique because there's been an upswing in fighting in the north, then you might be looking to ICRC" (L4) }\end{array}$ \\
\hline - $\quad$ History-based & $\begin{array}{l}\text { Local experience: "There is lots of historic information locally if the project has been running for a while. The local staff are the best in that" (E5) } \\
\text { Experience with a particular organisation: "sticking with the same partner who we've built a huge relationship with and works really well" (G2) }\end{array}$ \\
\hline - $\quad$ Necessity & $\begin{array}{l}\text { Expertise: "We need to stop trying to do things we don't understand. Only leave the final step into the disaster region for the NGO, outsource that } \\
\text { to one agency, and everything would be so much more efficient." (J3) } \\
\text { Goods: "they came up to us saying we are closing down a hospital or changing them in a hospital, so if you want them go and take them, they go } \\
\text { to a school now. We took all the computers and we had been notified of a shortage of laptops and computers in schools in Zambia" (D2) } \\
\text { Security: "there are also other local NGOs to consider, that's important even if you don't formally cooperate, you need to know what is going on } \\
\text { and that's also important for security reasons" (I4) } \\
\text { Growth: "we started doing our transport assessments, and we realised that, oh, if we had just talked to ICRC, as an example, we would have } \\
\text { noticed that they are actually already doing road transports to Yemen, and also cold chain, which is the more complex one by cooperating with } \\
\text { them by just asking the question, it opened a number of doors that lead to us, you know, I won't go into details, but led us to do some trial } \\
\text { shipments by road" (C4) }\end{array}$ \\
\hline \multicolumn{2}{|l|}{$\begin{array}{l}\text { Swift distrust } \\
\text { antecedents }\end{array}$} \\
\hline - Category & $\begin{array}{l}\text { Politics: "Generally, I would say, don't jump into bed with governments because the money they give can only be tied to certain projects. With the } \\
\text { way we operate, we can assign money to where it is really needed." (O1) } \\
\text { Military / Armed groups: "You know, obviously, negotiating with UN peace forces is not really the best partner for us." (C4) } \\
\text { Judgement against a type of organisation: "UN chums, they're the worst ones at giving that sort of info" (L4) } \\
\text { Values: "It's bitter, but it's true, nobody has an interest in making things better. They have an interest in keeping their own jobs that's all. And they } \\
\text { keep their jobs if they keep the people in the country small and the suffering continues" (F1) }\end{array}$ \\
\hline
\end{tabular}




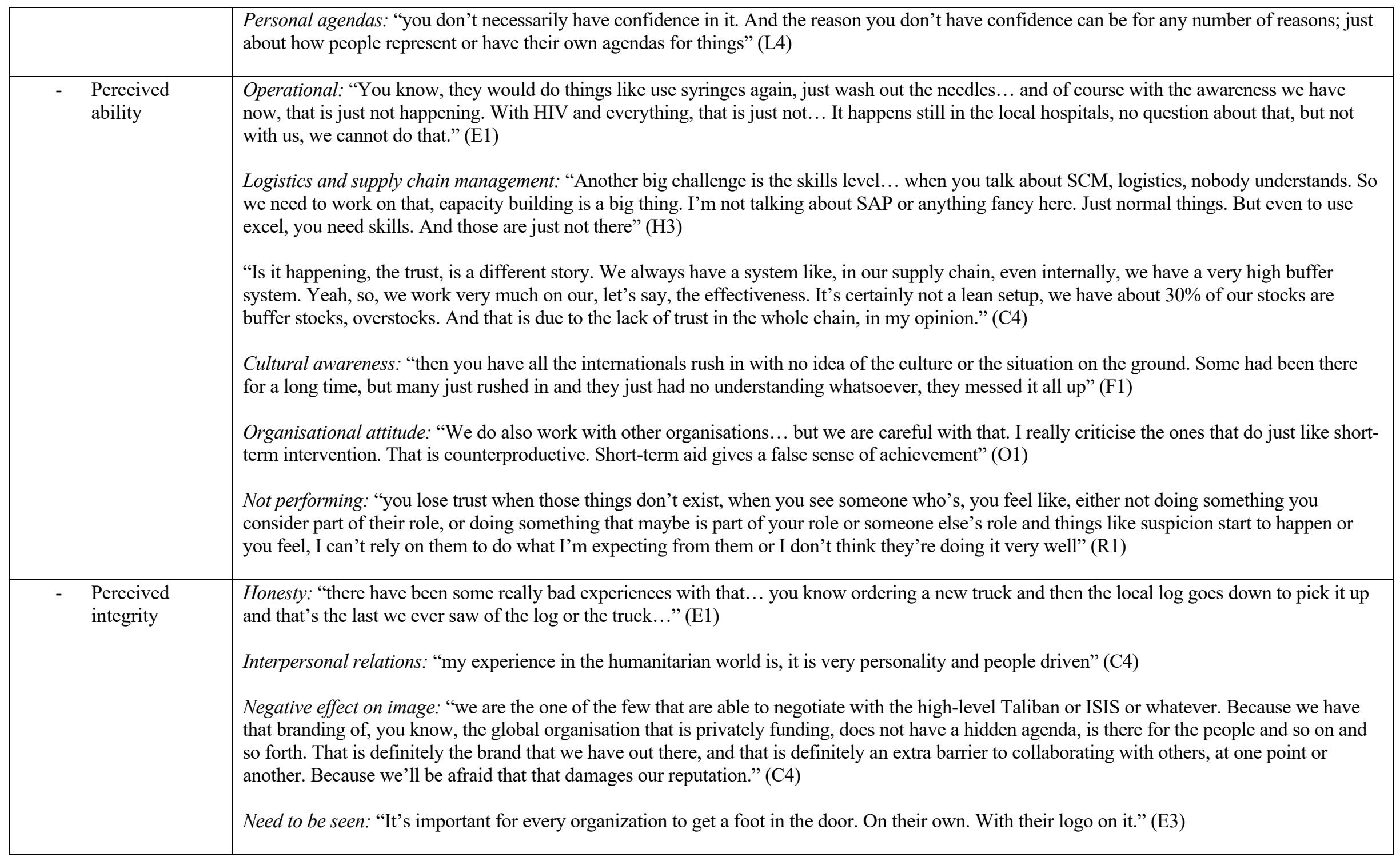




\begin{tabular}{|c|l|}
\hline - Governance & $\begin{array}{l}\text { Lack of regulation: "Unless you have some sort of strong regulatory environment that can provide that expertise like we have here in Europe but } \\
\text { most of the countries we work in, of course, even if the regulations are there the means to enforce regulations is just lacking in pretty much } \\
\text { everything" (B1) }\end{array}$ \\
$\begin{array}{c}\text { Inefficient control: "you do spend taking a lot of time up in meetings of which I've taken part of quite a lot and you're just literally going round in } \\
\text { circles saying the same thing every meeting" (I3) }\end{array}$ \\
$\begin{array}{l}\text { Duplication: "sometimes an organisation goes to a specific area, to a specific beneficiary and distributes aid and another organisation knows a } \\
\text { beneficiary has severe needs and so they go to the specific area and give him some cash or a voucher, so the beneficiary, at the end of the day, } \\
\text { takes a lot of humanitarian aid, while another beneficiary doesn't get anything. This is not fair for both of the parties" (Q1) }\end{array}$ \\
\hline History-based \\
$\begin{array}{l}\text { Character: "we tend to be very passionate, very emotional people. And this thing of a bad experience influencing the next experience, it certainly } \\
\text { happens over and over. That people say, we tried it before, it never worked, we tried working with them, this this and that happened. But it all } \\
\text { again comes down to individuals" (C4) }\end{array}$ \\
$\begin{array}{l}\text { Wider experience: "the history plays a major role. It influences every bit of work. I guess it is the same in all of the former colonies. Especially as } \\
\text { a Brit you have a lot of history there that is still very present in these countries" (I4) }\end{array}$
\end{tabular}

